\title{
КОНФЛИКТОЛОГИЯ
}

\author{
UDC 316(075.8)
}

\section{The return of the dictatorship: A new perception of modernity}

\author{
A. N. Danilov \\ Belarusian State University, \\ 4, pr. Nezavisimosti, Minsk, 220030, Republic of Belarus
}

For citation: Danilov A.N. The return of the dictatorship: A new perception of modernity. Vestnik of Saint Petersburg University. Philosophy and Conflict Studies, 2020, vol.36, issue 1, pp.105-115. https://doi.org/10.21638/spbu17.2020.109

The article discusses versions of fighting for the political future of the world, the results of which are not yet predetermined. Development of the political process in the twenty-first century illustrates that the world is entering a stage of permanent crisis of liberal democracy. The democratic wave of the 1990s died out and led only to the growth of right-wing extremism, nihilism and nationalism all over the world. It happened not only in the governments that arose out of dictatorships at the end of the twentieth century, but also in some old democracies. Democracy has ceased to cultivate authoritative and strong leaders. Society cannot always be in transformation or trauma state. Sooner or later a new reality will be built. Social anomia is not a permanent process, as it would inevitably become part of normative system. The new authoritarianism is cultivated by the ineffectiveness of power, disbelief in its ability to curb the situation of chaos and discontent, and to bring life back to normal. Today, no country in the world can be a model for imitation. There is not any ideal that others would like to borrow. Building a new ideal of civilizational development is fixed through the disclosure of a complex ethical system in which value conflict acts as an inevitable component. Most of the post-Soviet countries failed to advance their societies to a more suitable level of economy, to reach the positions dictated by the modern information age, and to provide the population with new high standards of living. Convergent trends are becoming increasingly noticeable in the Republic of Belarus with authoritarian rule. Evolutionary nature is inherent in the Belarusian transformation. It is based on the mentality of the people and the social responsibility of government. The post-Soviet world is not in a hurry to part with acquired sovereignty and is not ready to share even a part of its rights with supranational structures.

Keywords: democracy, new authoritarianism, world order, value conflict, transformation, post-Soviet world, new convergent society, sustainable development.

(c) Санкт-Петербургский государственный университет, 2020 
The result of the struggle for the political future of the world is not predetermined. The slogan "The road to hell is paved with good intentions" is surely applicable for all times Dictatorships often arose in the periods of crises, putsches, and revolutions as citizens' last hope for justice, law and order, their eternal desire to feel like they are someone to be reckoned with and heard. Today, the dictatorship is returning in the form of a new authoritarianism, in which much is allowed, but the future is not predictable because it is in the hands of one man, and he is not God.

The millennium was frightening due to its unpredictability, but it was also encouraging as it inspired hope for a peaceful and democratic future. It seemed to everyone that the worst connected with dictatorships was already behind them. People were ready to come to an agreement and the world would certainly become more stable, fairer, and kinder. The fall of the Berlin Wall and the collapse of the Soviet Union symbolized the victory of liberal democracy over the communist dictatorship. The new governments painfully experienced a "parade of sovereignties" and they were in a state of deep crisis. Democracy was perceived as permissive. The United States, the only remaining superpower, saw itself as a winner in the Cold War and dictated new standards of life to everyone, considering its domination as a guarantee of preserving the American-way, democratic order, and spreading it to the global world.

But time is evil ... Not even two decades of the twenty-first century have passed and nothing remains of the optimism of that time. Increasingly, analysts are forced to declare the crisis and even the collapse of liberal democracy. In this case, more well-founded arguments in favor of restoring order and strengthening power appeared. It is obvious that the democratic wave of the 1990s has choked... and only led to the growth of right-wing extremism, nihilism and nationalism all over the world. It happened not only in the governments that appeared from dictatorships at the end of the twentieth century, but also in some old democracies.

Sorokin was right when he wrote in "The Sociology of Revolution": "A society that does not know how to live, which is unable to develop by gradually reforming, therefore, entrusting itself to the crucible of revolution, is forced to pay for its sins with the death of most of its members. And this is the indemnity eternally demanded by the almighty Sovereign" [1, p. 294].

\section{New authoritarianism profile: gray and faceless...}

Democracy has ceased to cultivate authoritative and strong leaders. Society cannot always be in a state of transformation or trauma. Sooner or later a new reality will be created. Social anomia is not a permanent process; otherwise it fatally becomes the norm. But can global instability, crises, revolutions, endless changes of regimes, ideologies, life meanings, spiritual pillars, and faith become the norm?

Recent experience has shown that the pace and nature of changes in the political and economic system, as well as the predisposition to different forms of integration activity, largely depend on the structural, economic, ethno-cultural, political, and other concrete historical features of each country. In conditions of reforming the old system people often become hostages of events that they do not know how to manage, permanently remaining under social and psychological pressure. This is the main feature of the all transformational processes. 
Understanding this important historical stage has been delayed. Speaking only about the transitive state and not trying to comprehend where and by what rules the world is progressing seems wrong. One cannot but notice the aggravation of the struggle for a new world order. But who will determine its structure, on whose patterns will it be built, what will become the basis of new geopolitical realities, the basis of the moral solidarity, and the spiritual basis of the future civilization? Here, in my opinion, comes to the forefront the importance of scientific research today. The recent 'yesterday happened' and 'defeat in the "cold war" still does not say anything about the current situation.

The vacuum created in Europe due to permanent world crises, global instability, and the destruction of the system of checks and balances established after World War II is being filled with new authoritarianism [2, p. 17-32]. There is a shortage of leaders in the world who are capable of establishing policies that are adequate to meet new challenges. The new authoritarianism is cultivated by the weakness of power and skepticism in its ability to curb the situation of chaos and discontent, to return life back to normal. We cannot discount the weakness of the opposition, especially the liberal one, which failed to offer an acceptable alternative and also was built on the leader's autocracy.

New democratic governments failed to develop a policy system and give the legislation a socially oriented character to protect the materially vulnerable groups. The process of gradual erosion of democratic institutions in their latter form, the crisis of traditional political parties, political movements where party authoritarianism began to be felt and replace the collective will of the party is obvious. The underestimation of the cultural sphere, which is fraught with the strengthening of right-wing radicalism in society, contributes to the growth of nationalism, especially among young people. In such conditions, an appeal to an increasing number of citizens is becoming a call to restore order, protect traditional values, and preserve social guarantees.

The profile of the new authoritarianism is ambiguous. He is gray and faceless, politically populist. He is subtle in assessing the nuances of the modern political field. It is technologically aligned with the information revolution and new communication possibilities to influence the masses and manipulate them. The central question is not about a method of obtaining and maintaining political power, but a method of its implementation. There is an understanding that it is impossible not to take into account economic stagnation, the growth of inequality, and the complication of mobility processes. Crises are appearing more often in less wealthy countries with a feeling of growing social discontent. At the same time, the new authoritarianism is achieving great success on the periphery in countries that have left the dictatorship system recently. However, there are examples of authoritarianism spreading in countries of old democracies today.

It is obvious that the democratic institutions of the leading countries of the world are receding; the situation is becoming increasingly difficult to negotiate. And a strong government with weak leaders, parties, and civil institutions is also uncertain. External pressure on new independent countries is increasing in order to impose on them "guarantees of protection of sovereignty." Traditional methods of pressure on subjects of geopolitics on a particular state undergo structural and contextual transformation. Conventional traditional forms of pressure (economic blackmail, declaration of war, severing of diplomatic relations, trade embargo, pressure through international organizations, etc.) are being replaced by technologies for destabilization of political regimes, manipulation of public opinion, and waging information wars. 
In these circumstances, the content of the pressure object is revised. Instead of traditional objective forms of external pressure (the army, security system, the economy, political institutions, the redistribution of natural resources), values, beliefs, culture, behavioral attitudes, and life strategies are now the focus of accentuated negative impact. The main focus of pressure initiators has been switched to public opinion and value orientations. The content of impact tools in the objective sphere is also being reoriented. If the institutions were the object of influence previously (army, territory, economy), then in in the conditions of reformatting the areas of external pressure, concrete technologies of activating the destabilizing potential come to the forefront now. In this case, there is a process of transformation of institutional forms of accented pressure to external influence gaining a technological aspect. In the conditions of geopolitical instability and confrontation of geostrategic entities, technologies for destabilizing small countries' political systems in order to radically transform ruling political elites and change the vector of socio-economic development with subsequent involvement in the sphere of interests of a particular geopolitical subject become primarily important [3].

Why does a strong authoritarian leader become the "magic wand" in a difficult moment? He will draw a new shape of the country according to his own concepts, taking into account his assessment of the situation, level of his culture, and life values. Under his influence, reforms of state institutions will occur, a significant creative role will be given to youth and educational policy; a new model of socio-economic policy will be developed. The guarantee of his success is the momentary support of the people; his rating cultivated on populism. But can such an implementation of power result in a long-term program of sustainable development and build a convergent society where all the best accumulated by humanity will be embodied?

\section{Value conflict as a sure sign of impending change}

Democracy was unable to respond to modern challenges of the time and offer a new ideology. Today, no country in the world is a model for imitation and there is no ideal that others would like to borrow.

A new ideal of civilizational development is fixed through the disclosure of a complex developing ethical system in which the inevitable component is the value conflict. The modern world illustrates that the transformation of political and economic systems can be carried out in a short time. However, consciousness and socialization, which were acquired during over time, cannot undergo rapid changes. They continue to influence each other and may cause a crisis of an individual and a system in the process of adapting the new requirements.

The way out of this morbid state lies in the mechanisms of adaptation to the changing world. This very idea on the points of growth for a new civilization is confirmed by Stepin: "The ideal of progress as a process of accelerating innovation changes has been modified into the ideal of sustainable development today: priority is given to such innovative scenarios that not only can hack and destroy traditions, but, adapting to some of its aspects, selectively and gradually transform the tradition" $[4, \mathrm{p} .10]$. The option is very interesting itself. To maintain stability in development requires adaptation without failure and revolutions to assert a more progressive reality. Such a process is possible mainly with a strong government. Although any transition to a different development model takes place with 
a serious weakening of the old government institutions, it can lead to a complete loss of control and revolution.

The transformation process continues until the approval of some new foundations, which are fixed by the constitutional act of a sovereign country. Then the formation and rooting of the new statehood begins. This process can proceed quickly and over a long time. It can be peaceful, or it can be accompanied by armed clashes, protests, even civil disobedience, wars, and irreconcilable resistance. All that follows the formation of a new statehood will be referred to differently. The moment of completion of the next stage of the systemic transformation is still not clarified "because of its multi-criteria" [5, p.76]. The transformational stage can be complete when the main goal has been achieved and the tasks that were put forward by the initiators of the changes, which found their consolidation in the main constitutional act of the country, have been achieved and become the basis of the domestic and foreign policy of a sovereign state; in this case returning to the old system becomes impossible.

For more than a quarter of a century the post-Soviet world, it has been demonstrated that new countries behave differently in the choice of new priorities; the further they go, the more their paths diverge. In the ensuing chaos the priority is often given only to material ends - no ideology, historical and spiritual kinship, common values or traditions. Pragmatism dominates. Priority is given to strengthening the economic and military potential. Force once again becomes the main argument in the modern geopolitical game. Capitulation is a real threat for losing national identity; it creates a distorted, falsified matrix of values, and leads to the loss of an independent future. Even if the new integration formations appear in such conditions, it is mainly in the interests of protecting sovereignty, national and cultural identity.

Political ignorance, imitation of vigorous activity, has resulted in significant harm. Currently, there are symptoms of a deep ideological crisis, which is manifested in distrust, confusion, and paradoxical manifestations of human consciousness. The grounding of statehood, the awareness of sovereignty by the people, and the building up of national identity is a time of great trials. It involves new responsibilities, the desire to assert national kinship, to pass an identity test, and to feel a difference from the common past. There are a lot of temptations here so as not to fall into the extreme of nationalism, falsification of history, the presentation of mutual claims to the once common historical fate, reappraisal of recent common achievements, victories and defeats, and the contribution of intellectuals and national heroes.

Therefore, the new governments should have a consolidating goal in the form of an idea, theory, meaning, and moral example that can unite the majority of the people. And it is obligatory - the practice of a purposeful group of people, their infectious example, the ascetic, satisfied with their sacrificial way of life; traditions that are passed down from generations and happiness in everyday life. In contrast, disintegration begins with doubt, disbelief, nihilism, and the struggle for national exclusiveness.

People who have lost their memory are dreadful. Falsification of the past results in new tragedies, senseless battles, and useless sacrifices. The criminal actions of specific people who perpetrated putsches, sow evil, discord, hatred, violence and the death of innocent victims are most often behind such amnesia. Today, these are actions related to the de-Sovietization, the demolition of monuments to Soviet soldiers - the victors of World War II, the falsification of a common past. At the beginning of the twenty-first century, 
the forms and methods of external influence on governments that did not accept modern barbarism changed significantly. The current revolutions have become more sophisticated and diverse: "soft power" has come to replace the armed export of revolution and direct pressure; now it is influence through culture, values, lifestyle, etc. There are social networks, all sorts of public, educational and charitable foundations, and associations that involve obtaining foreign grants.

Today, terrorism is the main challenge in the twenty-first century, having an advantage of the chaos that arose with the collapse of the USSR, and it has taken deep root in the world. In a relatively short period of time, terrorism has created an extensive network of its structures. These world terrorist and extremist organizations, whose ideology is built on religious and nationalist fanaticism, are trying to revive medieval norms and values to create their own separate country. And no "controlled chaos" will help here. It turned out to be a strong and destructive weapon with its life world, people who do not want to live according to the laws of human civilization.

A country full of people who know nothing about their history and literature, who are not keen on the greatness of their own culture and who are not able to defend it - such a country is doomed to live on the sidelines of civilization.

\section{New convergent society and the transition to sustainable development}

Historically, both in the Soviet and post-Soviet periods, the meaning of the theory for an adequate understanding and explanation of modernity is clearly underestimated. In essence, the fundamental works of Russian thinkers on the problems of systemic transformation of the post-Soviet world remain unread or unknown (Kudryavtsev, Zaslavskaya, Yadov, Toshchenko, Gorshkov, Levashov, Kirdin and others). It is becoming increasingly difficult to interpret the new experience of state-building and the data of applied research, to adequately perceive and evaluate others' ideas without new theoretical instruments.

Despite the fact that Western theories have proved fruitless in explaining and anticipating the processes in the post-Soviet space, we cannot ignore them. In this regard, it is impossible to disregard those theoretical arguments that allow, at least partially, to diagnose modernity: the risk society (Toffler, Giddens, Beck, Lash, etc.), post-modern as flowing modernity (Bauman), McDonaldization (Ritzer), and the world-systemic paradigm (Wallerstein). They do not lose their relevance for the construction of scientifically based predictions of the Habermasian idea of the diagnosis of the time, Baudrillard's idea of simulacra, Huntington's clash of civilizations and others.

Attempts to apply a "Western model" of modernization did not lead the post-Soviet countries to the expected prosperity. New sovereign countries had to go undergo their own way of realizing what had happened and experience all the difficulties of systemic transformation from their own experience. Currently, there is an active search for concepts that could otherwise explain world processes. Nonetheless, foreign concepts have continued to circulate in post-Soviet humanitarian studies for decades until their complete isolation from context or the emergence of more adequate western concepts will not change the situation. Disbelief in the creative potential of Russian science is still far from being overcome.

Most of the post-Soviet governments failed to promote their societies to more adequate levels of the economy to reach the positions dictated by the modern information 
age and to provide the people with new higher standards of living. And this defeat befell the above-named governments after successfully solving a similar task, for a short time, both by capitalist (Singapore, Malaysia, South Korea) and socialist countries (China and Vietnam) [6, p. 215]. Former Singapore Prime Minister Lee Kuan Yew [7] who understood deeply the essence of modern changes in his forecast for the near future, wrote: "...our world and our life would be changed by the development of technologies in the field of communications and transport. $<\ldots\rangle$...the growth of migration will constitute a serious challenge for the future of interstate borders. $<\ldots .$. ...the swiftness of the modern world the dizzying speed with which all processes take place in it - has its negative aspects $\langle\ldots\rangle$ ...one cannot rush into liberalizing the movement of capital, especially if the financial system does not have enough stability $\langle\ldots\rangle$. ...The opening to the world should take place gradually after a certain level of maturity and reliability has been achieved $\langle\ldots\rangle$. ... Of course, society must retain a sense of proportion. Pure, unregulated capitalism is dangerous because it inevitably leads to revolts and a split in society. It is necessary to maintain a delicate balance. It is necessary to find ways to allow even the lowest strata to maintain a decent standard of living and to feel their belonging to society" [7, p. 356, 358-361].

The post-Soviet countries, in accordance with the old traditions, have developed as authoritarian. In these countries, strong leaders form new sovereign societies for themselves. They have different detailed scripts, and a general understanding of their omnipotence. Although today it has become clear to everyone that the transformation of the countries formed on the ruins of the Soviet Union is a phenomenon of the global historical order that has caused huge geopolitical shifts, the world will not acquire a new shape soon.

Is it possible to build a bright future without real guidelines, ideas about happiness, goodness, and morality? Why has Russia, despite visible success, not yet become a role model for post-Soviet youth? Why does most of the new generation tend to see their future in the West and focus on the Western way of life? This happened against the background of all the problems the West has today. Globalization has crushed the mystery of the human soul, it has generated a new wave of nationalism and ethnic inequality. Our ideas of conscience, honor, dignity, and morality need protection. Without the wealth of the human inner world, the era of ignorance, hypocrisy, and violence begins. The world of technology manipulates the most holy thing in a human - his conscience. We have to admit that we are building a society on someone else's patterns, with a "competent consumer" at the heart of the new universe. But how stable is this model? After all, these steps of Homo sapiens in a consumer society become not the pillars of personal freedom, happiness and well-being, but the source of selfishness, aggression, and human intolerance towards each other. The explanations lie in the field of modern morality. Today, deviations from the accepted rules of human life and behavior are signified as the norm. A family built on the love of a man and a woman is treated as an obsolete anachronism. Human sacrifice, asceticism, and the manifestation of heroism are ridiculed and ostracized, and morality is put at the forefront. This situation leads the world to chaos, people lose the ability to negotiate, and do not feel the need for dialogue. As a result, a small group of people have a real opportunity to completely rule the world. Theories previously perceived as the most fantastic utopias can turn into reality.

The root of evil of many modern difficulties and shortcomings is seen in the cultivation of the fundamental principles of modern market economy organization, which 
is directly oriented to the constant growth of consumption. In public opinion, attitudes towards wealth sharply fluctuate from its complete rejection and condemnation to the construction of a golden calf cult. Finding a middle ground here is an urgent task for the sustainable functioning of the future society. "The main problem of developing societal and economical convergent models is to find the right balance between the leading and controlling role of the state on the one hand, and the market sector operating on the basis of private property and competition, on the other. In short, in finding the optimal combination of planning and market, taking into account national specifics. In addition, in providing by government a social orientation of progress, social justice and increasing human capital" [8, p.71].

In Belarus, there is authoritarian rule and convergent tendencies are becoming increasingly noticeable. Here, a strong vertical of power was created and the social orientation of the political course was preserved. The transformation process is not yet fully completed, the consequences of the global financial crisis need to be overcome, the national economy will be brought to a new innovative stage, the agricultural sector will be modernized, and a high level will be reached in the development of the humanitarian sphere, science, education, and culture. The difficult process of forming a national identity is in full swing. Changes in the country are not an ultimatum. They are distinct and unacceptable for the Belarusian people. More and more in the minds of citizens the idea of the value of sovereignty, responsibility for their own destiny, and the fate of their country is being established.

The Belarusian transformation is inherent in the evolutionary nature, based on the mentality of the people and the social responsibility of government. The development model of Belarus in the last two decades can be defined as socially oriented. There is no doubt about the leading role of the government sector. The main function of the government is precisely to create the necessary conditions for the economical and the social sphere, to ensure the safety of citizens, social justice and social order, and to resist corruption and protectionism. Political stability is one of the most important factors for the gradual integration of Belarus into the world economy as it attracts foreign investment. Another feature of the Belarusian model is that the private sector can and should develop along with the state, but not to the detriment of national interests. A specific feature of the Belarusian model is permanent privatization that is aimed at finding an interested investor, to create an efficient and honest owner.

The collapse of the existing system of social protection of the people, the deepening of social polarization, and the deterioration of the living conditions of vulnerable groups of the population are not allowed in Belarus. Belarusian social policy not only helps people in dire need, but also makes continuous investments in health care, professional, cultural, and personal development of citizens. Attention is paid to training the younger generation, to its practice-oriented education. The implemented model of development meets the requirements of the present, the collectivist traditions of the Belarusian people, and supports the idea of the creation of a strong government precisely through an evolutionary path. Of course, new risks and challenges require fast and adequate action. Some deviations from the accepted model are quite possible, but the principles that will exclude the possibility of using shock therapy should remain unshakable.

In my opinion, the world will be strengthened not by adopting common-to-all rules of the game, universal human values, but due to respect (including by the powers that 
be) of national interests, rights and advantages of all peoples and citizens, and fostering a dialogue of cultures. Recognition of the lifestyle and the development model of the strongest as a model results in the surrender of one's own national interests and, thus, receding of one's own cultural foundations, changing the identification code, and the loss of the future. Historical experience just rejects the hegemony of one country or a group of developed western countries: such an alignment of forces has already demonstrated the impossibility of adequately responding to contemporary challenges and correctly solving problems. A quarter of a century of the post-Soviet world shows that not one of the countries formed on the ruins of the former socialist community is in a hurry to part with their acquired sovereignty and is not ready to share even part of their rights with supranational structures.

\section{Conclusion}

Obviously, changes are global and lead to the formation of a new civilization. Currently, there is a battle for the political future of the world. Dictatorships often arose in periods of crises, putsches, revolutions as the last hope of citizens for justice, law and order. The new profile of authoritarianism is gray and faceless. Democracy has ceased to cultivate authoritative and strong leaders. As recent experience shows, the pace and nature of changes in the political and economic system, as well as the predisposition to one or another form of integration activity, largely depends on the structural, economic, ethnocultural, political, and other historical features of each country. The recent "yesterday" and defeat in the "cold war," still does not say anything today. There is a shortage of leaders in the world who are capable of building policies that are adequate to the new challenges. The new authoritarianism is cultivated by the weakness of power, unbelief in its ability to curb the situation of chaos and disorder, to bring life back to normal. We cannot discount the weakness of the opposition, especially the liberal one, which has failed to offer an acceptable alternative and is also built on the leader's autocracy.

The main problem is not a method of obtaining and maintaining power, but a method of its implementation. It is obvious that the democratic institutions of the leading countries of the world are slipping, and it is becoming increasingly difficult to negotiate. And a strong government with weak leaders, parties, civil institutions is also unpromising. Conventional traditional forms of pressure (economic blackmail, declaration of war, severing of diplomatic relations, trade embargo, pressure through international organizations, etc.) are replaced by technologies of destabilization of political regimes, manipulation of public opinion, and informational wars.

Building a new shape of civilization is fixed through the disclosure of a complex evolving value system, where value conflict is an inevitable component. Now there are symptoms of a deep ideological crisis, which is manifested in distrust, confusion, and paradoxical manifestations of human consciousness. Falsifying the past condemns us to new tragedies, senseless battles and useless sacrifices.

Most of the post-Soviet countries failed to advance their societies to more adequate economic levels, to reach the positions dictated by the modern information age, to provide the population with new higher standards of living.

It is hard to not conclude with the words of the great Lee Kuan Yew, which could become an epigraph for my reflections: "We must accept the world as it is and look for a 
way that will allow society to confidently develop and keep up with rapidly changing time. Remember: The Earth will not cease to rotate for your sake" [7, p. 362].

\section{References}

1. Sorokin, P. A. (1992), "Sociology of revolution", Man. Civilization. Society, Politizdat Publ., Moscow, pp. 266-295. (In Russian)

2. Antonovich, I. I., Danilov, A. N. (2018), Geopolitics in an era of instability, Belaruskaia navuka Publ., Minsk, 383 p. (In Russian)

3. Danilov, A. N., Rotman, D. G. (2019), The priority of soft power in the destabilization of modern society (on the example of the Republic of Belarus), Sociological studies, no. 2, pp. 68-77.

4. Stepin, V.S. (2017), Civilization in the era of change: the search for new development strategies, Journal of the Belarusian State University. Sociology, no. 3, pp. 6-11.

5. Yadov, V. A. (2006), Modern theoretical sociology as a conceptual base for the study of Russian transformations, Intersocis Publ., St. Petersburg, 112 p. (In Russian)

6. Toshchenko, Zh.T. (2019), Society of injury: objective reality or zigzag in historical development, Global Development: Challenges of Predictability and Manageability: International Likhachov Scientific Conference, St. Petersburg University of the Humanities and Social Sciences Press, pp. 214-218. (In Russian)

7. Yu, Lee Kuan (2017), My view of the future of the world, Alpina non-fiction Publ., Moscow, $446 \mathrm{p}$. (In Russian)

8. Tsagolov, G. N. (2016), New Integral Society: General Theoretical Aspects and World Practice, LENAND Publ., Moscow, 256 p. (In Russian)

Received: April 30, 2019

Accepted: December 11, 2019

Author's information:

Alexander N.Danilov — Dr. Sci. in Sociology, Professor; a.danilov@tut.by

\section{Возвращение диктатуры: новое прочтение современности}

\section{А. Н. Данилов}

Белорусский государственный университет, Республика Беларусь, 220030, Минск, пр. Независимости, 4

Для цитирования: Danilov A.N. The return of the dictatorship: A new perception of modernity // Вестник Санкт-Петербургского университета. Философия и конфликтология. 2020. Т. 36. Вып. 1. С. 105-115. https://doi.org/10.21638/spbu17.2020.109

В статье рассмотрены варианты борьбы за политическое будущее мира, итоги которой еще не предрешены. Развитие политического процесса в XXI в. показывает, что мир входит в стадию перманентного кризиса либеральной демократии. Демократическая волна 1990-х годов захлебнулась и привела лишь к нарастанию по всему миру правого экстремизма, нигилизма и национализма. Причем не только в государствах, которые вышли из диктатур в конце XX в., а и в некоторых старых демократиях. Демократия перестала культивировать авторитетных и сильных лидеров. Общество не может постоянно находиться в состоянии трансформации или травмы, рано или поздно выстраивается новая реальность. Социальная аномия все же процесс не перманентный, иначе он неизбежно становится нормой. Новый авторитаризм взращен бессилием власти, неверием в ее возможность обуздать ситуацию хаоса и недовольства, вернуть жизнь в нормальное русло. Сегодня в мире ни одна страна не является образцом для 
подражания, нет идеала, заимствовать который стремились бы другие. Выстраивание нового идеала цивилизационного развития фиксируется через раскрытие сложной развивающейся этической системы, где неизбежным компонентом выступает ценностный конфликт. Большинство постсоветских государств не сумели продвинуть свои общества на более достойные уровни экономики, выйти на позиции, диктуемые современной информационной эпохой, предоставить населению новые высокие стандарты жизни. В Республике Беларусь с авторитарным правлением становятся все более заметными конвергентные тенденции. Белорусской трансформации присущ эволюционный характер преобразований, основанный на ментальности народа и социальной ответственности власти. Постсоветский мир не спешит расставаться с обретенным суверенитетом и не готов делиться даже частью своих прав с некими наднациональными структурами.

Ключевые слова: демократия, новый авторитаризм, мировой порядок, ценностный конфликт, трансформация, постсоветский мир, новое конвергентное общество, устойчивое развитие.

Статья поступила в редакцию 30 апреля 2019 г.; рекомендована в печать 11 декабря 2019 г.

Контактная информация:

Данилов Александр Николаевич — чл.-кор. НАН Беларуси, д-р социол. наук, проф.; a.danilov@tut.by 